\title{
Distribution pattern of anurans from three mountain complexes in southeastern Brazil and their conservation implications
}

\author{
MATHEUS O. NEVES ${ }^{1}$, ELVIS A. PEREIRA ${ }^{2}$, JOSÉ LUIZ M.M. SUGAI ${ }^{1}$, SABINE \\ B. DA ROCHA ${ }^{1}$, RENATO N. FEIO ${ }^{3}$ and DIEGO J. SANTANA ${ }^{1}$ \\ ${ }^{1}$ Programa de Pós-Graduação em Ecologia e Conservação, Universidade Federal de Mato Grosso do Sul, \\ Instituto de Biociências, Cidade Universitária, Pioneiros, 79070-900 Campo Grande, MS, Brazil \\ ${ }^{2}$ Programa de Pós-Graduação em Biologia Animal, Universidade Federal Rural do Rio de \\ Janeiro, Rodovia BR 465, Km 7, s/n, Zona Rural, 23890-000 Seropédica, RJ, Brazil \\ ${ }^{3}$ Programa de Pós-Graduação em Biologia Animal, Departamento de Biologia Animal, Museu de Zoologia João \\ Moojen, Universidade Federal de Viçosa, Avenida Peter Henry Rolfs, s/n, 36570-000 Viçosa, MG, Brazil
}

Manuscript received on March 23, 2017; accepted for publication on December 20, 2017

\begin{abstract}
Biogeographic tools support spatial distribution pattern hypotheses and help to determine priority areas for conservation. Our aim was to verify biogeographic patterns for anurans in three mountain complexes in southeastern Brazil, as well as to discuss the status of species conservation recorded and the biogeographical units evaluated. We selected 16 areas distributed in the Serra da Mantiqueira complex, south of Serra do Espinhaço and Serra da Canastra. We used the occurrence (geographic coordinates) of each species in the localities to determine areas of endemism applying the Endemicity Analysis method. We also tested whether similarity between areas was explained by geographic distance (Multiple Regression on distance Matrices-MRM). The Serra do Itatiaia, Serra da Canastra, Plateau of Poços de Caldas and Serra do Cipó were the areas that presented the highest number of species restricted to them. Through the Endemicity Analysis, we identified four areas of endemism with higher scores. The MRM revealed that the geographic distance explained $41 \%$ of species dissimilarity between areas. Most of the endemic species from these areas have inaccurate conservation statuses (data deficient or unevaluated). These results highlight the need for greater research efforts towards understanding species restricted by distribution, as well as the priority in conserving these endemic areas.
\end{abstract}

Key words: endangered species, endemism, highlands, Mantiqueira Complex, Serra da Canastra, Serra do Espinhaço.

\section{INTRODUCTION}

Processes that maintain and produce biological diversity are complex and difficult to measure (Cassemiro and Padial 2008). Currently, the

Correspondence to: Matheus de Oliveira Neves

E-mail: nevesmo@yahoo.com.br uplift of the Andean mountain chain in the middle Miocene, has been considered the main geologic event structuring the biota in South America (Chaves et al. 2015). Glaciation events and marine transgressions occurred in the upper and middle Miocene, they are also responsible for the exchange of South American fauna (Zanella 2011), 
contributing to the high biological diversity of the continent. This high biodiversity has generated hypothesis about their patterns of establishment, supported by the Pleistocene forest refugia theory (Haffer 1969) and the seasonally dry tropical forest (Prado 2000).

Linking distributional data of species and studying areas of endemism is essential for a better view on the biogeography of a given area (Brown et al. 1996, Goldani and Carvalho 2003, Carstensen et al. 2013). Also, it is possible to see the pattern of similarity of species between biogeographic areas considering different variables, such as, vegetation cover of the region, geographic barriers, and distance between evaluated areas (Serafim et al. 2008, Santos et al. 2009). The use of biogeographic tools also helps with mapping priority areas for conservation (e.g., Goldani and Carvalho 2003). Some informations of the group studied are fundamental as premise for biogeographic studies, such as knowledge about phylogeny and levels of species endemism. As well as previous information of their spatial distributions, and capacity and limits of their dispersion (Goldani and Carvalho 2003).

Although amphibians inhabit several types of environments and are adapted to adverse situations, such as extreme cold or desert climates (Duellman and Trueb 1986), amphibians are vulnerable animals, highlighted as the group that are most affected by climate change and human disturbance (Verdade et al. 2010). Consequently, the group is generally used as an indicator of environmental disturbances (Verdade et al. 2010).

In Southeastern Brazil, the three mountain complexes, the Serra da Mantiqueira, south of Serra do Espinhaço, and Serra da Canastra, present high amphibian diversity (Cruz and Feio 2007, Leite et al. 2008, Barros 2011). Several studies conducted in these regions (e.g., Cruz and Feio 2009, Moura et al. 2012, Pirani et al. 2012, Pimenta et al. 2014a, b, Neves et al. 2017a, b) allowed us to develop database for the present study. These informations also make possible evaluate the historical biogeography of the region and delimit endemism areas in order to implement conservation areas for environmental preservation (Domínguez et al. 2006, Chaves et al. 2015). Through this historical evaluation it is possible to determine patterns of species distribution occurring in these high altitude areas (surrounded by Atlantic Forest and Cerrado, hotspots of biodiversity). In this study, we have three main goals: (1) we aim identify areas of endemism in these three mountainous regions, (2) as well as to test whether anuran species composition is more similar in more proximal areas, and (3) also we sought to provide conservation aspects and distribution patterns of anurans of these three montain complexes.

\section{METHODS}

\section{STUDY AREA}

The region studied is located in the southeast of Brazil, between two global hotspot of biodiversity, the Cerrado and Atlantic Forest (Mittermeier et al. 2004). We analyze studies developed in three complex mountains: Serra da Mantiqueira, Serra do Espinhaço, and Serra da Canastra (Figure 1).

The Serra da Mantiqueira complex extends over the borders between the Brazilian States of Minas Gerais with São Paulo, Rio de Janeiro, and Espírito Santo in Atlantic Forest biome, for the most part. This mountain complex is inaccurately delimited, varying between authors. For this study, we divided the extension into two distinct regions, North Mantiqueira (MN) and South Mantiqueira (MS) (Cruz and Feio 2007) (Figure 1). These regions are divided by a lowland, with some tributaries of the Paraíba do Sul river, such as the Pomba River, Muriaé River, Carangola River and Itabopoana River. The highest altitude areas are located in the Serra do Caparaó (MN) and in the Serra do Itatiaia (MS). The Serra do Espinhaço extends approximately $1000 \mathrm{~km}$ along the States 


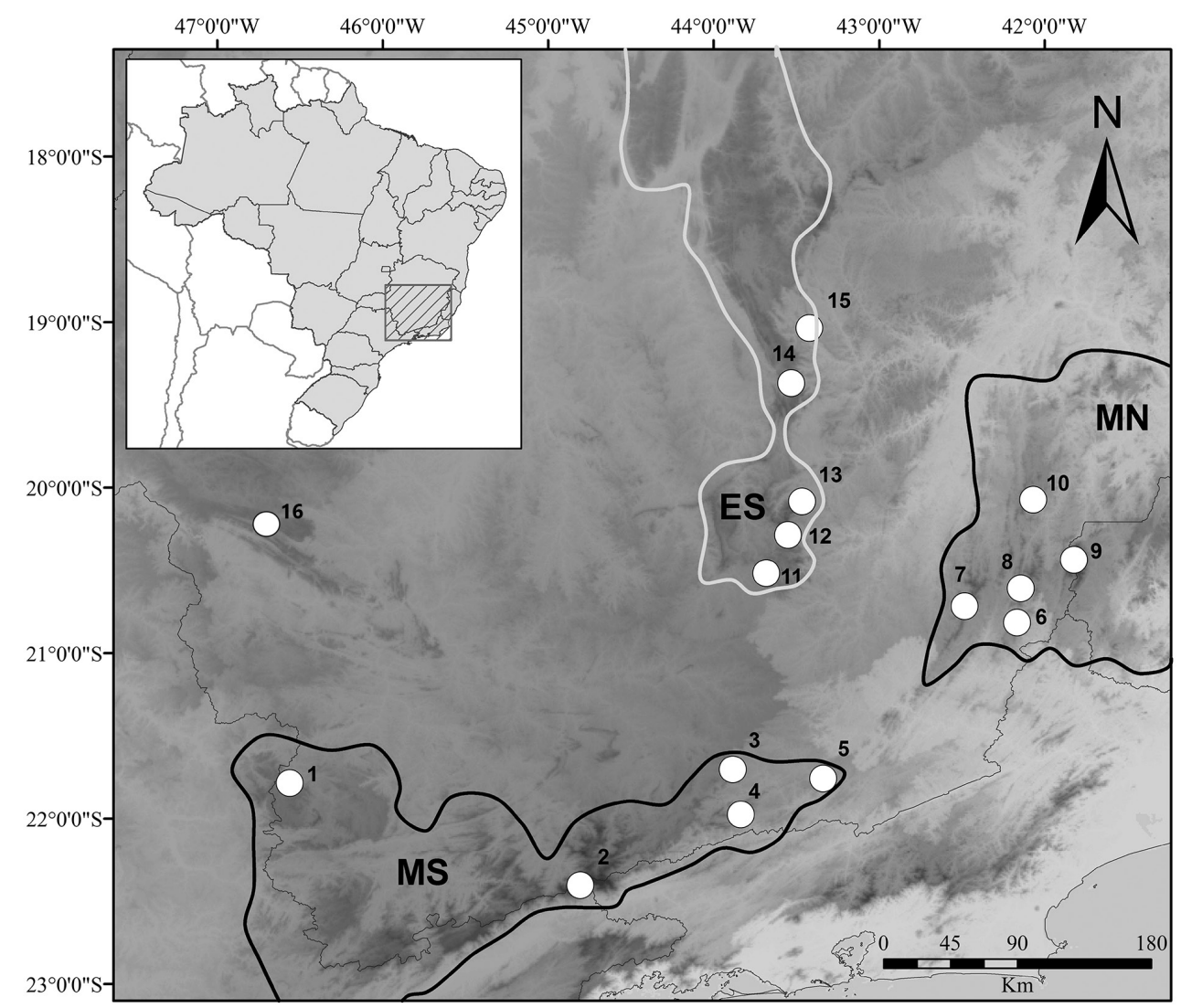

Figure 1 - Demarcation adopted for the Serra da Mantiqueira complex and Serra do Espinhaço and the localities used in this study: (1) Plateau of Poços de Caldas, (2) Serra do Itatiaia, (3) PE do Ibitipoca, (4) Serra Negra, (5) Municipality of Juiz de Fora, (6) Pedra Dourada, (7) Serra do Brigadeiro, (8) Municipality of Divino, (9) Serra do Caparaó, (10) Municipality of Simonésia, (11) Municipality of Ouro Branco, (12) Floresta Estadual do Uaimií, Municipality of Ouro Preto, (13) Serra do Caraça, (14) Serra do Cipó, (15) Microregion of Conceição do Mato Dentro and (16) Serra da Canastra. MS: South of Serra da Mantiqueira; MN: North of Serra da Mantiqueira; ES: South of Serra do Espinhaço.

of Minas Gerais and Bahia. It is situated between two ecological hotspots, the Cerrado and Atlantic forest, as well as the Caatinga in its northern portion (Leite 2012). Altitudes of this mountain range vary between 800 and 1900 meters, and is characterized by rupestrian fields with predominantly sandstone and quartzite soils (Giulietti and Pirani 1988, Silva et al. 2005). In our analysis, we used information from the South of Espinhaço (ES). The Serra da Canastra is located predominantly in a crystalline plateau isolated from other mountains complexes studied and presents altitudes ranging from 800 to 1496 m (Romero and Martins 2002).
We selected 16 areas of high altitude from this region (Table I). To run the analysis the selected regions had to have a minimum altitude of 650 meters but greater than 1000 meters. We selected 10 localities in the Serra da Mantiqueira complex (MS: Serra Negra, Parque Estadual do Ibitipoca, Municipality of Juiz de Fora, Serra do Itatiaia, and Plateau of Poços de Caldas; and MN: Pedra Dourada, Serra do Brigadeiro, Municipality of Divino, Serra do Caparaó, and Municipality of Simonésia), five localities in the ES (Floresta Estadual do Uaimí́, Municipality of Ouro Branco, Serra do Caraça, Serra do Cipó and Microregion 
TABLE I

Areas used in the analysis with varying altitudes, Number of species recorded, Corrected number of species used, and their references.

\begin{tabular}{|c|c|c|c|c|}
\hline Locality & Altitude & $\begin{array}{c}\mathrm{N}^{\mathbf{o}} \\
\text { species }\end{array}$ & $\begin{array}{c}\mathrm{N}^{\mathbf{o}} \\
\text { revised }\end{array}$ & References \\
\hline Serra Negra & $846-1698 m$ & 48 & 43 & Pinheiro et al. 2016, Neves et al. 2017a \\
\hline Parque Estadual do Ibitipoca & $1050-1784 \mathrm{~m}$ & 41 & 36 & Cruz et al. 2009 \\
\hline Municipality of Juiz de Fora & $650-1000 \mathrm{~m}$ & 47 & 40 & Neves et al. $2017 \mathrm{~b}$ \\
\hline Serra do Itatiaia & $2791 \mathrm{~m}$ & 68 & 61 & $\begin{array}{l}\text { Werner 1903, Lutz 1926, Cochran 1938, 1948, Lutz and } \\
\text { Carvalho 1958, Lutz 1968a, IBDF 1982, Heyer 1983, } \\
\text { Izecksohn and Gouvêa 1987, Peixoto 1989, Peixoto and } \\
\text { Cruz 1992, Haddad and Pombal Jr 1995, Caramaschi and } \\
\text { Cruz 2004, Targino et al. 2009, Pimenta et al. 2014b }\end{array}$ \\
\hline Pedra Dourada & $1300 \mathrm{~m}$ & 39 & 36 & Neves 2014 \\
\hline Serra do Brigadeiro & $1600 \mathrm{~m}$ & 59 & 50 & Moura et al. 2012, Guimarães et al. 2017 \\
\hline Municipality of Divino & $700-1500 \mathrm{~m}$ & 40 & 37 & Hote 2016 \\
\hline Serra do Caparaó & $2892 \mathrm{~m}$ & 41 & 32 & IBDF 1981, Heyer 1982 \\
\hline Municipality of Simonésia & $1180-1626$ & 30 & 23 & Santos 2015 \\
\hline Floresta Estadual do Uaimií & $900-1400 \mathrm{~m}$ & 37 & 35 & Pirani et al. 2012 \\
\hline Municipality of Ouro Branco & $900-1600 m$ & 47 & 47 & São-Pedro and Feio 2011 \\
\hline Serra da Caraça & $900-2000 \mathrm{~m}$ & 45 & 40 & $\begin{array}{c}\text { Afonso and Eterovick 2007, Canelas and Bertoluci 2007, } \\
\text { Baêta and Silva } 2009\end{array}$ \\
\hline Serra do Cipó & $1200 \mathrm{~m}$ & 43 & 37 & Eterovick and Sazima 2004 \\
\hline $\begin{array}{l}\text { Microregian of Conceição } \\
\text { do Mato Dentro }\end{array}$ & $1600 \mathrm{~m}$ & 58 & 51 & Pimenta et al. 2014a \\
\hline Plateau of Poços de Caldas & $1500 \mathrm{~m}$ & 33 & 32 & $\begin{array}{c}\text { Lutz 1966, 1968b, Andrade and Cardoso 1987, Giaretta } \\
\text { and Sazima 1993, Caramaschi and Cruz 2004, Monteiro- } \\
\text { Leonel 2004, Vasconcelos and Giaretta } 2005\end{array}$ \\
\hline Serra da Canastra & $800-1496 m$ & 39 & 35 & $\begin{array}{c}\text { Barros 2011, Caramaschi and Napoli 2012, Lourenço et } \\
\text { al. 2013, Pimenta et al. 2015 }\end{array}$ \\
\hline
\end{tabular}

of Conceição do Mato Dentro), and the Serra da Canastra (Figure 1).

\section{SPECIES COMPOSITION}

We inventoried the anuran community from high altitude areas of the Serra da Mantiqueira Complex, the South of Serra do Espinhaço, and Serra da Canastra using the database of anuran surveys from these regions (Table I). We updated these databases with information from studies about species descriptions, species revisions, and geographic distribution records. Using information from recent articles we corrected or removed questionable species (classified as nomenclature aff., sp., and cf.), except Proceratophrys sp. which is in the process of being describe (PS Hote personal communication). We verified conservation status of endemic species from the Serra da Mantiqueira complex, Serra da Canastra and south of Serra do Espinhaço according to the Red list of Internacional Union for Conservation of Natures (IUCN 2016), the list of Brazilian endangered animals of the Instituto Chico Mendes de Conservação da Biodiversidade (ICMBio 2014), and the lists from the States of Minas Gerais (Drummond et al. 2008), Rio de Janeiro (Bergallo et al. 2000), São Paulo (Bressan et al. 2009), and Espírito Santo (Passamani and Mendes 2007). 


\section{BIOGEOGRAPHIC ANALYSES}

To show biogeographic patterns and areas of endemism of the regions, we first used traditional methods which involve the mapping and superposition of species distributions. We considered an area of endemism when there were at least two species that had restricted distribution, or did not occur in any other area.

To complement the traditional methods we also used the occurrence (geographic coordinates) of each species in this localities to determine areas of endemism applying the Endemicity Analysis method (Szumik et al. 2002, Szumik and Goloboff 2004). This analysis maps the spatial occurrence of each species, calculates an index of endemicity (IE) for each one and selects areas through the overlap of their geographic distribution. The endemicity value of each area selected (score) represents the sum of the IE of all species present. In order to keep only one locality in each area unit (pixel), since they represent mountain peaks isolated by altitudinal differences, we used pixel size of 0.3 X 0.3 degrees. We saved localities sets with more than two endemic species and score (endemicity value) higher than two. We used the NDM/VNDM software version 3.1 for the area selection (Goloboff 2004). We present the endemicity areas selected in maps made with Quantum GIS software version 2.18.4 (Quantum GIS Development Team 2017).

We calculated geographic distance between areas (available coordinates from other studies) using Euclidian distance and species similarity using the Jaccard Index. Afterwards we used a Multiple Regression on Distance Matrices (MRM), proposed by Lichstein (2007), to evaluate how geographic distance explains similarity of species. For data analysis we used R v 3.3.0 (R Core Team 2016) software, with the packages vegan (Oksanen et al. 2016) and ecodist (Goslee and Urban 2007).

\section{RESULTS}

\section{SPECIES COMPOSITION}

We analyzed a total of 635 individuals, a total of 182 anurans species distributed in 14 families: Brachycephalidae (14), Bufonidae (7), Centrolenidae (3), Ceratophrynidae (1), Craugastoridae (3), Cycloramphidae (8), Dendrobatidae (1), Eleutherodactylidae (1), Hemiphractidae (1), Hylidae (81), Hylodidae (17), Leptodactylidae (32), Microhylidae (4), and Odontophrynidae (9). The Serra do Itatiaia was the richest area (61 species), followed by the microregion of Conceição do Mato Dentro (51 species) and Serra do Brigadeiro (50 species). Sixty-four of the 182 species were restricted to either the Serra da Canastra, the South of Serra do Espinhaço and/ or to the Serra da Mantiqueira complex.

The species conservation status, according to the International Union for Nature Conservation (IUCN 2016), had 1.79\% presenting some degree of endangerment (i.e., Critically Endangered CR, Endangered - EM and Vulnerable - VU), $29.31 \%$ were data deficient (DD) and $12.57 \%$ were not evaluated. When we considered just endemic species of the region $(n=64)$ these values increased to $3.2 \%$ for some degree of threat, $51.56 \%$ for data deficient and $28.2 \%$ were not evaluated (Figure 2).

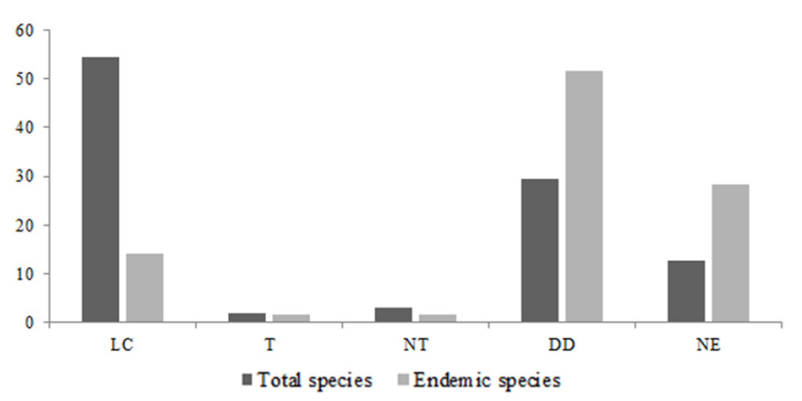

Figure 2 - Percentage of species in each conservation status according to the IUCN Red list (2016). Dark gray bars indicate the total species recorded $(n=182)$; Light gray bars indicate endemic species to the Serra da Canastra, South of Espinhaço and the Mantiqueira complex $(n=64) . \quad L C=$ Least concern; $\mathrm{T}=$ under some degree of threat (Critically Endangered, Endangered, Vulnerable); NT = Near Threatened; DD = Data deficient; and $\mathrm{NE}=$ not evaluated. 


\section{BIOGEOGRAPHY OF THE REGION}

The distribution pattern of amphibians in the Serra da Mantiqueira complex presents species that occur just over their extension (34 endemic species), as well as species that occur only in MS (22 spp.) and MN (seven spp.) portions. On the other hand, the ES presents 23 endemic species. The other species present peculiar distribution patterns, including dispersal between two of the study mountains: the distribution of Ischnocnema izecksohni ranges from both portions of the Serra da Mantiqueira complex and the South of Serra do Espinhaço; Bokermannohyla nanuzae occurs in the South of Espinhaço and South of Serra da Mantiqueira complex; I. surda, Hylodes babax, and Physalaemus maximus occur in the South of Espinhaço and in the North of the Serra Mantiqueira complex.

Many species registered in this study present large distributions in the study area and most of them $(64.8 \%, n=118)$ exceed the borders of the study area. Among the species recorded in this study, $11.1 \%$ occurred in more than 10 localities, $42.9 \%$ were recorded between two to nine localities, and $45 \%$ was restricted to one locality.
Among species evaluated with the traditional method, 29 presented distributions restricted to a single mountain unit. Areas with the highest endemism were in the Serra do Itatiaia with nine endemic species (Ischnocnema concolor, I. melanopygia, Holoaden bradei, Bokermannohyla gouveai, Boana latistriata, Hylodes glaber, $H$. regius, Megaelosia lutzae, and Paratelmatobius lutzae), followed by the Serra da Canastra with five species (Vitreorana franciscana, Bokermannohyla ibitiguara, Scinax pombali, Crossodactylus franciscanus and Odontophrynus monachus). We also highlighted four species recorded in the Plateau of Poços de Caldas (Bokermannohyla vulcaniae, Scinax caldarum, Scinax ranki, and Proceratophrys palustris), three species of the Serra do Cipó (Scinax pinima, Physalaemus deimaticus, and Pseudopaludicola mineira), while two species were recorded for the Serra do Caparaó (Cycloramphus bandeirensis and Hylodes vanzolinii) and Serra Negra (Hylodes perere and Boana cambui). Though presenting a single species in each area, the Serra do Brigadeiro (Brachycephalus darkside) and, the Municipality of Juiz de Fora (Adelophryne meridionalis) harbor

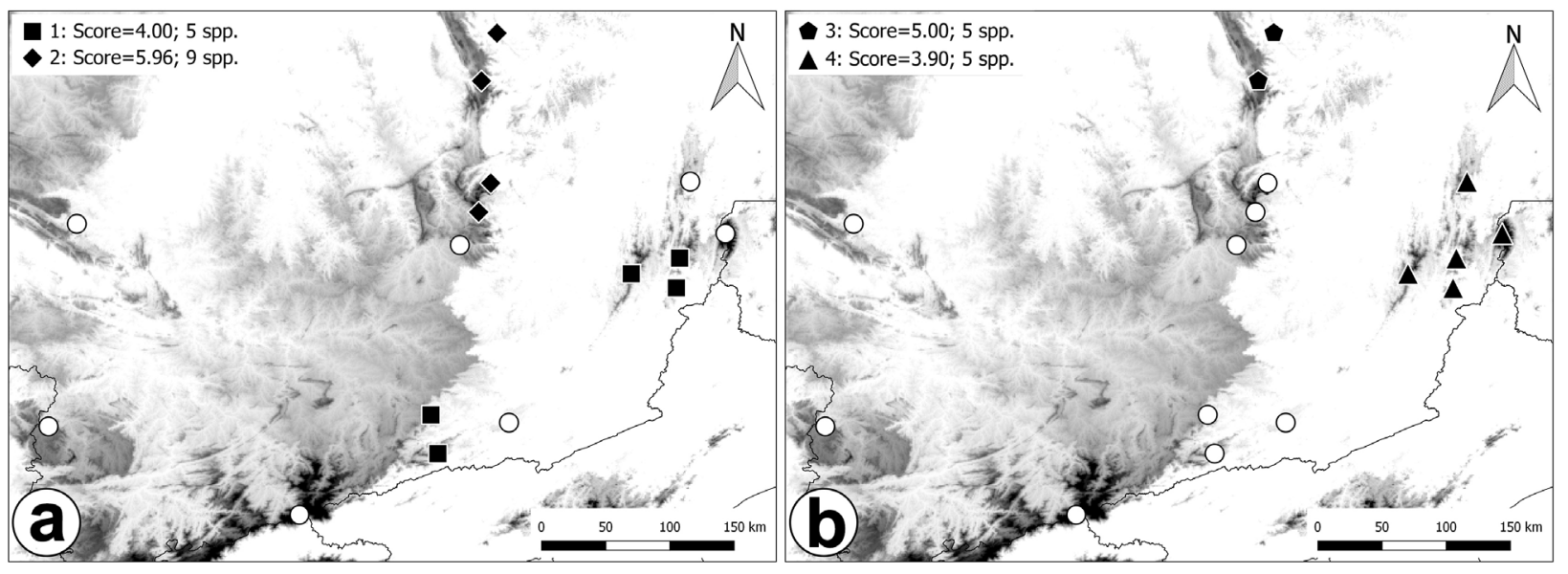

Figure 3 - The four areas of endemism generated by EA with their scores and number of species, separated in two maps: (a) Area of endemism one with PE do Ibitipoca, Serra Negra, Pedra Dourada, Serra do Brigadeiro and Municipality of Divino, and area of endemism two with Floresta Estadual do Uaimií, Serra do Caraça, Serra do Cipó and Microregion of Conceição do Mato Dentro. (b) Area of endemismo three with Serra do Cipó and Microregion of Conceição do Mato Dentro, and area of endemismo four with Pedra Dourada, Serra do Brigadeiro, Municipality of Divino, Serra do Caparaó and Municipality of Simonésia. 
species that, until now, were only recorded in these areas (Table SI - Supplementary Material).

Using the Endemicity Analysis we were able to identify four areas of endemism with higher scores (Figure 3): the first area comprises three localities from northern and two from southern Serra da Mantiqueira (Figure 3a); the second comprises most of the points (four of five) located at southern Serra do Espinhaço (Figure 3a); the third comprises two localities from southern Serra do Espinhaço (Figure 3b); the fourth comprises all the points located at northern Serra da Mantiqueira (Figure $3 b)$. The area two has the higher score (5.96), followed by area three (5.00), area one (4.00) and area four (3.90), respectively. Higher number of species contributing to the area's endemicity value was also found at area two (nine species), followed by the other three areas (five species).

The MRM test showed that geographic distance explained $41 \%$ of species dissimilarity between evaluated areas $\left(\mathrm{R}^{2}=41, \mathrm{p}=0.001\right)$.

\section{DISCUSSION}

\section{BIOGEOGRAPHY OF THE REGION}

Regions of altitude are areas with high degrees of endemism due to the genetic isolation of the population in different areas, as occurs in every extension of the Serra da Mantiqueira complex (Cruz and Feio 2007) and the Serra do Espinhaço (Leite et al. 2008). In the mountain areas of the southeast of Brazil, the vicariant processes that occurred in the region until the quaternary (Gatto et al. 1983) have nowadays revealed a great number of endemic species in the region, as confirmed for amphibians, and other groups such as birds (Chaves et al. 2015) and plants (Rapini et al. 2008). However, it is expected that this panorama will increase as taxonomic revisions are provided for complexes of cryptic species (e.g., Rhinella gr. crucifer by Thomé et al. 2010, Ischnocnema guentheri by Gehara et al. 2013, Proceratophrys melanopogon by Mângia et al. 2014).

The area of endemism two generated by EA comprise the southern Serra do Espinhaço Complex (excepted Ouro Branco) with high score (Score $=5.96)$. For Cerrado anurans and squamates, the region of southern Serra do Espinhaço had also been recovered as an endemism area (Azevedo et al. 2016). When evaluating the pattern of endemicity in bird distribution in the southeast mountains of Brazil, Chaves et al. (2015) revealed geographic barriers to the gene flow, reinforcing the separation of the endemism areas showed by the pattern of amphibian distribution. In the southern Serra do Espinhaço, geographic barriers separate the area three generated by EA (Serra do Cipó and Conceição do Mato Dentro) to the others localities (Chaves et al. 2015). They also found a genetic barrier between the Southern Regions of the Serra da Mantiqueira complex and the region of Poços de Caldas (Chaves et al. 2015).

The Plateau of Poços de Caldas, considered by some authors as part of the Serra da Mantiqueira complex (Valverde 1958, Cruz and Feio 2007), proved to be a uniqueand separated area of endemism that unites the other locations of the complex of Serra da Mantiqueira. The phytophisionomy factors may explain part of this similarity due to the strong influence of the Cerrado in this location, which is emphasized by species like Rhinella rubescens, Phyllomedusa ayeaye, and Odontophrynus cultripes (Valdujo et al. 2012). Furthermore, the volcanic formation that characterizes the highlands of Poços de Caldas (Schorscher and Shea 1992) also shows a differentiated geology in this region when compared to the rest of the Serra da Mantiqueira complex, making these highlands a unique and representative area of endemism for the anurans of the region.

There are common species found in both Serra do Espinhaço and Serra da Mantiqueira mountain complexes that confirm the relation of proximity 
between these two locations. Species that are phylogenetically close with similar habitats in different geographic units suggest biogeographical homologies (Morrone 2001). Physalaemus deimaticus, $P$. erythrus and P. rupestris are species phylogenetically related (Lourenço et al. 2016), and occur in three different mountains (Baêta and Silva 2009). Due to their habitat and restrict distribution, the mountain complexes where they occur were suggested to have an ancient connection (Cruz and Feio 2007) confirming such biogeographical homologies in the studied area. Besides that, some historical events validate this relationship due to the fact that the Serra do Espinhaço use to be covered by Rainforest until the middle of the Oligocene (Maxson and Heyer 1982), presenting relict species in this domain. Another important factor to be considered is the continuous altimetry of 800 meters that extends from the Serra do Ibitipoca region to the Quadrilátero Ferrífero, connecting the southern portion of the Serra do Espinhaço to the Serra da Mantiqueira complex (Cruz and Feio 2007).

The geographic distance between the sampled areas explained $41 \%$ of the dissimilarity; this result indicated by the MRM is expected (Hubbel 2001). This inverse proportion between the geographic distance and the similarity between areas was registered in other works with anurans (Bertoluci et al. 2007, Santos et al. 2009), also associated with mountainous complexes of the Serra do Mar (Giasson 2008) and some other locations in the southern part of the Serra da Mantiqueira complex (Juarez 2011). The geographic distance is just one more variable that influences the pattern of anuran species distribution, which may also be controlled by the vegetation, hydro period, and topography of the analyzed region (Serafim et al. 2008, Santos et al. 2009).

\section{CONSERVATION OF SPECIES AND ENDEMISM} AREAS

The connection of endemism areas is fundamental for those who search for the conservation of biodiversity (Brown et al. 1996, Goldani and Carvalho 2003), because these locations are key for investments in protection and environmental studies. Although slow in comparison to the declining amphibian populations (Verdade et al. 2010), studies have been done in the Serra da Mantiqueira complex and South of Serra do Espinhaço. Cruz and Feio (2007) indicated a total of 63 endemic species in the Serra da Mantiqueira complex, with 36 restricted to only one biogeographic unit. However, due to the taxonomic dynamic, the magnification of species distribution areas, and the description of new species, this number is already outdated. Furthermore, reports of the decrease in local populations were already recorded for Cycloramphus granulosus and Hylodes glaber in the Serra do Itatiaia (Heyer et al. 1988), mainly due to anthropic actions, such as pollution, introduction of exotic species, deforestation, and consequently habitat fragmentation (Pimenta et al. 2014a).

Species with restricted distribution are of greatest concern and need to be studied, because most have conservation statuses classified as data deficient or unevaluated (Figure 2). These type of studies are necessary to allocate species to their actual conservation categories (Bland et al. 2012). In the last years, few studies have been developed about endangered species or data deficient species, with only $16 \%$ of the studies published between 2000 and 2010 targeting these animals (Campos et al. 2014). This lack of information is due to the difficulty to access areas where these species are distributed, as well as to the habits of these species, mostly being nocturnal and/or cryptozoic (Morais et al. 2013).

The Serra do Itatiaia was the area with the highest richness and endemic species, which is 
protected to Parque Nacional do Itatiaia (IBDF 1982). Among the species present there, occurs the critically endangered Holoaden bradei (IUCN 2016). Besides, most areas of endemism found by the EA are protected, such as the Parque Nacional da Serra da Canastra, Parque Nacional da Serra do Cipó, and Parque Nacional do Caparaó. However, the Plateau of Poços de Caldas has just a small area protected by the Jardim Botânico de Poços de Caldas, which configure this region as an important area that presents critically endangered species, such as Bokermannohyla vulcaniae and Proceratophrys palustris (ICMBio 2014). However, it is unclear how far the boundaries of these protected areas contain these endemic species and how they are conserved.

Although more surveys efforts are necessary in some areas, such as the area one generated by EA, composed by Serra Negra, Divino and Pedra Dourada, which is not protected, the other areas are protected by the Parque Estadual do Ibitipoca and Parque Estadual da Serra do Brigadeiro, and together configure an area of endemism. The same occurs with areas of endemism four protected by the Parque Nacional do Caparaó and Parque Estadual da Serra do Brigadeiro. Nevertheless, these isolated highland areas have a necessity for conservation actions due to their unique biota.

The largest part of the Serra da Mantiqueira complex is located in Minas Gerais State, where approximately $20 \%$ of its vegetal cover remains due to the destruction of large natural areas (Valor Natural 2005). The Ecological Corridor of Mantiqueira, which includes some areas of endemism present in the Southern portion of Serra da Mantiqueira complex (except Plateau of Poços de Caldas and the Municipality of Juiz de Fora), is ideal for connecting fragmented areas, as well as encouraging scientific research and environmental education for the local populations of the municipalites involved (Valor Natural 2005).
Though there are efforts in the conservation of endemic and endangered species of these mountains areas with great biodiversity, it is still not sufficient due the rapid anthropization and consequent loss of habitat. Increasing studies like the present work, with punctual focus on the conservation areas and endangered species, need to be clarified for this knowledge to generate concrete results about the conservation of mountain areas in southeastern Brazil.

\section{ACKNOWLEDGMENTS}

We are thankful to Ana Carolina Resende and Hannah Doerrier for the helpful reviews provided. To Pedro Romano, Emanuel Teixeira da Silva, Eliana Faria Oliveira and Sarah Mangia for their help in preparing this manuscript. We thank the Coordenação de Aperfeiçoamento de Pessoal de Nível Superior (CAPES) for the scholarship granted to MON, SBR and EAP.

\section{REFERENCES}

AFONSO LG AND ETEROVICK PC. 2007. Spatial and temporal distribution of breeding anurans in streams in southeastern Brazil. J Nat Hist 41(13-16): 949-963.

ANDRADE GV AND CARDOSO AJ. 1987. Reconhecimento do grupo rizibilis: descrição de uma nova espécie de Hyla (Amphibia, Anura). Rev Bras Zool 3: 443-440.

AZEVEDO JAR, VALDUJO PH AND NOGUEIRA CC. 2016. Biogeography of anurans and squemates in the Cerrado hotspot: coincidente endemismo patterns in the richest and most impacted savana on the globe. J Biogeogr 43(12): 2454-2464.

BAÊTA D AND SILVA DH. 2009. Amphibia, Anura, Leiuperidae, Physalaemus erythros Caramaschi, Feio and Guimarães-Neto 2003: Distribution extension. Check List 5(4): 812-814.

BARROS AB. 2011. Herpetofauna do Parque Nacional da Serra da Canastra, Minas Gerais, Brasil. Tese de Doutorado, Universidade Federal de Viçosa, Viçosa, 119 p.

BERGALO HG, ROCHA CFD, ALVES MAS AND VANSLUYS M. 2000. A fauna de extinção do Estado do Rio de Janeiro, Editora da UFRJ. Rio de Janeiro, Brasil, 166 p. BERTOLUCI J, BRASSALOTI RA, RIBEIRO JÚNIOR JW, VILELA VMFN AND SAWAKUCHI HO. 2007. Species 
composition and similarities among anuran assemblages of forest sites in southeastern Brazil. Sci Agric 64(4): 364-374.

BLAND LM, COLLEN B, ORME CDL AND BIELBY J. 2012. Data uncertainty and the selectivity of extinction risk in freshwater invertebrates. Divers Distrib 18: 1211-1220.

BRESSAN PM, KIERULFF MCM AND SUGIEDA AM. 2009. Fauna ameaçada de extinção no Estado de São Paulo: Vertebrados, Fundação Parque Zoológico de São Paulo: Secretaria do meio Ambiente. São Paulo, Brazil, 645 p.

BROWN JH, STEVENS GC AND KAUFMAN DM. 1996. The geographic range: Size, shape, boundaries and internal structure. Annu Rev Ecol Evol Syst 27: 597-623.

CAMPOS FS, BRITO D AND SOLÉ M. 2014. Diversity patterns, research trends and mismatches of the investigative efforts to amphibian conservation in Brazil. An Acad Bras Cienc 86: 1873-1886.

CANELAS MA AND BERTOLUCI J. 2007. Anurans of the Serra do Caraça, southeastern Brazil: species composition and phenological patterns of calling activity. Iheringia, Série Zoologia 97(1): 21-26.

CARAMASCHI U AND CRUZ CAG. 2004. Duas novas espécies de Hyla do grupo H. polytaenia Cope, 1870 do sudeste do Brasil (Amphibia, Anura, Hylidae). Arq Mus Nac 62: 247-254.

CARAMASCHI U AND NAPOLI MF. 2012. Taxonomic revision of the Odontophrynus cultripes species group, with description of a new related species (Anura, Cycloramphidae). Zootaxa 3155: 1-20.

CARSTENSEN DW, LESSARD JP, HOLT BG, BORREGAARD MK AND RAHBEK C. 2013. Introducing the biogeographic species pool. Ecography 36: 1310-1318.

CASSEMIRO FAZ AND PADIAL AA. 2008. Teoria neutra da biodiversidade e biogeografia: Aspectos teóricos, impactos na literatura e perspectivas. Oecol Bras 12(4): 706-719.

CHAVES AV, FREITAS GHS, VASCONCELOS MF AND SANTOS FR. 2015. Biogeographic patterns, origin and speciation of the endemic birds from eastern Brazilian mountaintops: a review. Syst Biodivers 2014: 1-16.

COCHRAN DM. 1938. Diagnoses of new frogs from Brazil. Proc Biol Soc Wash 51: 41-42.

COCHRAN DM. 1948. A new subspecies of frog from Itatiaia, Brazil. Am Mus Novit 1375: 1-3.

CRUZ CAG AND FEIO RN. 2007. Endemismos em anfíbios em áreas de altitude na Mata Atlântica no sudeste do Brasil. Herpetologia no Brasil II. In: Nascimento LB and Oliveira ME (Eds), Sociedade Brasileira de Herpetologia, $1^{\text {a }}$ ed., Belo Horizonte, Brasil, p. 117-126.

CRUZ CAG, FEIO RN AND CARAMASCHI U. 2009. Anfíbios do Ibitipoca, Bicho do Mato Editora, $1^{\mathrm{a}}$ ed., $132 \mathrm{p}$.

DOMÍNGUEZ MC, ROIG-JUÑENT S, TASSIN JJ, OCAMPO FC AND FLORES GE. 2006. Areas of endemism of the Patagonian steppe: an approach based on insect distributional patterns using endemicity analysis. J Biogeogr 33: 1527-1537.

DRUMMOND GM, MACHADO ABM, MARTINS CS, MENDONÇA MP AND STHEMANN JR. 2008. Listas vermelhas das espécies de fauna ameaçadas de extinção em Minas Gerais, Fundação Biodiversitas. Belo Horizonte, $2^{\mathrm{a}}$ ed., CD-ROM.

DUELLMAN WE AND TRUEB L. 1986. Biology of Amphibians, JHU Press, $670 \mathrm{p}$.

ETEROVICK PC AND SAZIMA I. 2004. Anfíbios da Serra do Cipó, Minas Gerais - Brasil, Editora PUC-Minas. Belo Horizonte, $1^{\mathrm{a}}$ ed., $151 \mathrm{p}$.

GATTO LCS, RAMOS VLS, NUNES BTA, MAMEDE L, GÓES MHB, MAURO CA, ALVARENGA SM, FRANCO EMS, QUIRICO AF AND NEVES LB. 1983. Geomorfologia. In: Levantamento de Recursos Naturais, v. 32, Projeto Radambrasil, Ministérios de Energias e Minas, Secretaria Geral, Brasília, Brasil, p. 305-384.

GEHARA M, CANEDO C, HADDAD CFB AND VENCES M. 2013. From widespread to microendemic: molecular and acoustic analyses show that Ischnocnema guentheri (Amphibia: Brachycephalidae) is endemic to Rio de Janeiro, Brazil. Conserv Genet 14: 973-982.

GIARETTA AA AND SAZIMA I. 1993. Nova espécie de Proceratophrys Mir. Rib. do sul de Minas Gerais, Brasil (Amphibia, Anura, Leptodactylidae). Rev Bras Biol 53: 13-19.

GIASSON LOM. 2008. Atividade sazonal e uso do ambiente por anfíbios da Mata Atlântica no alto da Serra do Mar. Tese de Doutorado, Universidade Estadual Paulista, Instituto de Biociências, Rio Claro, São Paulo, Brasil, 149 p.

GIULIETTI AM AND PIRANI JR. 1988. Patterns of geographic distribution of some plant species from the Espinhaço Range, Minas Gerais and Bahia, Brazil. In: Vanzolini PE and Heyer WR (Eds), Proceedings of a workshop on Neotropical distribution patterns, Academia Brasileira de Ciências, Rio de Janeiro, Brasil, p. 39-69.

GOLDANI Â AND CARVALHO GS. 2003. Análise de parcimônia de endemismo de cercopídeos neotropicais (Hemiptera, Cercopidae). Rev Bras Entomol 47(3): 437-442.

GOLOBOFF PA. 2004. NDM/VNDM, programs for identification of areas of endemism. Program and documentation. Available at: www.zmuc.dk/public/ phylogeny/endemism.

GOSLEE SC AND URBAN DL. 2007. The ecodist package for dissimilarity-based analysis of ecological data. J STAT SOFTW 22(7): 1-19.

GUIMARÃES CS, LUZ S, ROCHA PC AND FEIO RN. 2017. The dark side of pumpkin toadlet: a new species of Brachycephalus (Anura: Brachycephalidae) from Serra do Brigadeiro, southeastern Brazil. Zootaxa 4258: 327-344.

HADDAD CFB AND POMBAL JR JP. 1995. A new species of Hylodes from southeastern Brazil (Amphibia, Leptodactylidae). Herpetologica 51: 279-286. 
HAFFER J. 1969. Speciation in Amazonian Forest Birds. Science 165(3889): 131-137.

HEYER WR. 1982. Two new species of the frog genus Hylodes from Caparaó, Minas Gerais, Brasil (Amphibia: Leptodactylidae). Proc Biol Soc Wash 95: 377-385.

HEYER WR. 1983. Variation and systematics of frogs of the genus Cycloramphus (Amphibia, Leptodactylidae). Arquivos de Zoologia 30: 235-239.

HEYER WR, RAND AS, CRUZ CAG AND PEIXOTO OL. 1988. Decimation, extinctions, and colonization of frog population in southeast Brazil and their evolutionary implication. Biotropica 20(3): 230-235.

HOTE P. 2016. Composição da anurofauna e influência da estrutura de floresta na comunidade de anuros de duas APAS no corredor ecológico Brigadeiro-Caparaó. Tese de Mestrado. Universidade Federal de Viçosa, Viçosa, Brasil. (Unpublished).

HUBBEL SP. 2001. The unified neutral theory of biodiversity and biogeography, Princeton University Press. Princeton, New Jersey, USA, 392 p.

IBDF - INSTITUTO BRASILEIRO DE DESENVOLVIMENTO FLORESTAL. 1981. Fundação Brasileira para Conservação da Natureza. Plano de Manejo: Parque Nacional de Caparaó. IBDF, FBCN, Brasília, Brasil, 139 p.

IBDF - INSTITUTO BRASILEIRO DE DESENVOLVIMENTO FLORESTAL. 1982. Fundação Brasileira para Conservação da Natureza. Plano de Manejo: Parque Nacional do Itatiaia. IBDF, FBCN, Brasília, Brasil, $207 \mathrm{p}$.

ICMBIO - INSTITUTO CHICO MENDES DE CONSERVAÇÃO À BIODIVERSIDADE. 2014. Listas Nacionais de Espécies Ameaçadas de Extinção. ICMBio, Brasília, Distrito Federal, Brasil.

UCN - INTERNATIONAL UNION FOR CONSERVATION OF NATURE RED LIST OF THREATENED SPECIES. 2016. Version 2016-3. Available at: http://www.iucnredlist. org. Accessed on January 10, 2017.

IZECKSOHN E AND GOUVÊA É. 1897. Nova espécie de Megaelosia de Itatiaia, Estado do Rio de Janeiro. Arquivos de Universidade Federal Rural do Rio de Janeiro 8: 17-22.

JUAREZ AM. 2011. Diversidade de anfíbios anuros na Serra da Mantiqueira, na região do Pico dos Marins. Tese de Mestrado. Universidade Estadual Paulista, São José do Rio Preto, São Paulo, Brasil, 132 p. (Unpublished).

LEITE FSF. 2012. Taxonomia, biogeografia e conservação dos anfíbios da Serra do Espinhaço. Tese de Doutorado. Universidade Federal de Minas Gerais, Belo Horizonte, Brasil, 409 p.

LEITE FSF, ETEROVICK PC AND JUNCÁ FA. 2008. Status do conhecimento, endemismo e conservação de anfíbios anuros na Serra do Espinhaço, Brasil. Megadiversidade 4(1-2): 158-176.
LICHSTEIN JW. 2007. Multiple regression on distance matrices: a multivariate spatial analysis tool. Plant Ecol 188(2): 117-131.

LOURENÇO ACC, CARVALHO ALG, BAÊTA D, PEZZUTI TL AND LEITE FSF. 2013. A new species of the Scinax catharinae group (Anura: Hylidae) from Serra da Canastra, southeastern state of Minas Gerais, Brazil. Zootaxa 3613: 573-588.

LOURENÇO LB, TARGUETA CP, BALDO D, NASCIMENTO J, GARCIA PCA, ANDRADE GV, HADDAD CFB AND RECCO-PIMENTEL SM. 2016. Phylogeny of frogs from the genus Physalaemus (Anura, Leptodactylidae) inferred from mitochondrial and nuclear gene sequences. Mol Phylogenet Evol 92(2015): 204-216.

LUTZ A. 1926. Observações sobre batrachios brasileiros. Mem Inst Oswaldo Cruz 19: 139-174.

LUTZ B. 1966. Pithecopus ayeaye, a new brazilian hylid with vertical pupils and grasping feet. Copeia 1966: 236-240.

LUTZ B. 1968a. Geographic variation in Brazilian species of Hyla. Pearce-Sellards Series, Texas Memorial Museum, Austin 12: 1-13.

LUTZ B. 1968b. New Brazilian forms of Hyla. Pearce-Sellards Series, Texas Memorial Museum, Austin 10: 3-18.

LUTZ B AND CARVALHO AL. 1958. Novos anfíbios anuros das Serras Costeiras do Brasil. Mem Inst Oswaldo Cruz 56: 239-249.

MÂNGIA S, SANTANA DJ, CRUZ CAG AND FEIO RN. 2014. Taxonomic review of Proceratophrys melanopogon (Miranda-Ribeiro, 1926) with description of four new species (Amphibia, Anura, Odontophrynidae). Bol Mus Nac Nova Sér Zool 531: 1-33.

MAXSON LR AND HEYER WR. 1982. Leptodactylid frogs and the Brasilian Shield: an old and continuing adaptive relationship. Biotropica 14(1): 10-15.

MITTERMEIER RA, GIL PR, HOFFMANN M, PILGRIM J, BROOKS T, MITTERMEIER CG, LAMOREUX J AND DA FONSECA GAB. 2004. Hotspots revisited: Earth's biologically richest and most endangered terrestrial ecoregions, Conservation International, $392 \mathrm{p}$.

MONTEIRO-LEONEL AC. 2004. Herpetofauna do Planalto de Poços de Caldas, sul de Minas Gerais. Tese de Doutorado. Instituto de Biociências of Universidade de São Paulo, São Paulo, Brasil, 87 p.

MORAIS AR, SIQUEIRA MN, LEMES P, MACIEL NM, MARCO JR P AND BRITO D. 2013. Unraveling the conservation status of Data Deficient species. Biol Conserv 166(2013): 98-102.

MORRONE JJ. 2001. Homology, biogeography and areas of endemism. Divers and Distrib 7: 297-300.

MOURA MR, MOTTA AP, FERNANDES VD AND FEIO RN. 2012. Herpetofauna da Serra do Brigadeiro, um remanescente de Mata Atlântica em Minas Gerais, Sudeste do Brasil. Biota Neotrop 12(1): 209-235. 
NEVES CP. 2014. Composição e distribuição espaçosazonal de anfíbios em um fragmento de Mata Atlântica no município de Pedra Dourada - MG, Brasil. Tese de Mestrado. Universidade Federal de Viçosa, Viçosa, Brasil, 67 p. (Unpublished).

NEVES MO, FERREIRA VG, FONSECA EM, CERON K, VERELA-RIOS CH AND CARVALHO RMH. $2017 \mathrm{~b}$. Amphibians of Juiz de Fora municipality, Zona da Mata of Minas Gerais State, Brazil. Oecologia Australis 21(4): 374-384.

NEVES MO, PEREIRA EA, LIMA LMC, FOLLY H, OLIVEIRA EF, SANTANA DJ AND FEIO RN. 2017a. Anurans of Serra Negra da Mantiqueira, Zona da Mata of Minas Gerais, Brazil: a priority area for biodiversity conservation. Herpetology Notes 10: 297-311.

OKSANEN J, BLANCHET FG, KINDT R, LEGENDRE P, MINCHIN PR, O'HARA RB, SIMPSON GL, SOLYMOS P, STEVENS MHH AND WAGNER H. 2016. vegan: Community Ecology Package. R package version 2.3-5.

PASSAMANI M AND MENDES SL. 2007. Espécies da fauna ameaçadas de extinção no estado do Espírito Santo, Instituto de Pesquisas da Mata Atlântica. Vitória, Espírito Santo, Brasil, p. 140.

PEIXOTO OL. 1989. Duas espécies de Ololygon do grupo perpusilla (Amphibia, Anura, Hylidae). Arquivos de Universidade Federal Rural do Rio de Janeiro 11: 27-37.

PEIXOTO OL AND CRUZ CAG. 1992. New species of Hyla from the "Serra da Mantiqueira, Itatiaia, Rio de Janeiro" State - (Amphibia, Anura, Hylidae). Mem Inst Oswaldo Cruz 87: 197-200.

PIMENTA BVS, CARAMASCHI U AND CRUZ CAG. 2015. Synonymy of Crossodactylus bokermanni Caramaschi \& Sazima, 1985 with Crossodactylus trachystomus (Reinhardt \& Lütken, 1862) and description of a new species from Minas Gerais, Brazil (Anura: Hylodidae). Zootaxa 2955(1): 65-82.

PIMENTA BVS, COSTA D, MURTA-FONSECA R AND PEZUTTI T. 2014a. Anfíbios: Alvorada de Minas, Conceição do Mato Dentro, Dom Joaquim: Minas Gerais, Bicho do Mato. Belo Horizonte, Minas Gerais, Brasil, 196 p.

PIMENTA BVS, CRUZ CAG AND CARAMASCHI U. 2014b. Taxonomic review of the species complex of Crossodactylus dispar A. Lutz, 1925 (Anura, Hylodidae). Arquivos de Zoologia 45: 1-33.

PINHEIRO DP, PEZZUTI TL, LEITE FSF, GARCIA PCA, HADDAD CFB AND FAIVOVICH J. 2016. A New Species of the Hypsiboas pulchellus Group from the Serra da Mantiqueira, Southeastern Brazil (Amphibia: Anura: Hylidae). Herpetologica 72(3): 256-270.

PIRANI RM, NASCIMENTO LB AND FEIO RN. 2012. Anurans in a forest remnant in transition zone between cerrado and atlantic rain forest domains in southeastern Brazil. An Acad Bras de Cienc 85: 1093-1104.
PRADO DE. 2000. Seasonally dry forests of tropical South America: from forgotten ecosystems to a new phytogeographic unit. Edinb J Bot 57: 437-461.

QUANTUM GIS DEVELOPMENT TEAM. 2017. Quantum GIS Geographic Information System. Open Source Geospatial Foundation Project. http://qgis.osgeo.org.

R CORE TEAM. 2016. R: A language and environment for statistical computing. R Foundation for Statistical Computing, Vienna, Austria.

RAPINI A, RIBEIRO PL, LAMBERT S AND PIRANI JR. 2008. A flora dos campos rupestres da Cadeia do Espinhaco. Megadiversidade 4(1-2): 15-23.

ROMERO R AND MARTINS AB. 2002. Melastomataceae do Parque Nacional da Serra da Canastra, Minas Gerais, Brasil. Rev Bras Bot 25(1): 19-24.

SANTOS PS. 2015. Estrutura da comunidade de anuros de um fragmento de Mata Atlântica do Sudeste do Brasil: composição de espécies, uso de habitat e sazonalidade. Tese de Doutorado, $37 \mathrm{p}$.

SANTOS TG, VASCONCELOS TS, ROSSA-FERES DC AND HADDAD CFB. 2009. Anurans of seasonally dry tropical forest: Morro do Diabo State Park, São Paulo State, Brazil. J Nat Hist 43(15-16): 973-993.

SÃO-PEDRO VA AND FEIO RN. 2011. Anuran species composition from Serra do Ouro Branco, southernmost Espinhaço Mountain Range, State of Minas Gerais, Brazil. Check List 7(5): 671-680.

SCHORSCHER HD AND SHEA ME. 1992. The regional geology of the Poços de Caldas alkaline complex: mineralogy and geochemistry of selected nepheline syenites and phonolites. J Geochem Explor 54(1-3): 25-51.

SERAFIM H, IENNE S, CICCHI PJP AND JIM J. 2008. Anurofauna de remanescentes de floresta Atlântica do município de São José do Barreiro, Estado de São Paulo, Brasil. Biota Neotrop 8(2): 69-77.

SILVA AC, PEDREIRA LCVSF AND ABREU PAA. 2005. Serra do Espinhaço Meridional: paisagens e ambientes. $\mathrm{O}$ Lutador. Belo Horizonte, Brasil, 272 p.

SZUMIK CA, CUEZZO F, GOLOBOFF P AND CHALUP AE. 2002. An optimality criterion to determine areas of endemism. Syst Biol 5: 806-816.

SZUMIK CA AND GOLOBOFF PA. 2004. Areas of endemism: an improved optimality criterion. Syst Biol 53: 968-977.

TARGINO M, DA COSTA PN AND CARVALHO-E-SILVA SP. 2009. Two new species of the Ischnocnema láctea species series from Itatiaia highlands, southeastern Brazil (Amphibia, Anura, Brachycephalidae). South Am J Herpetol 4: 139-150.

THOMÉ MTC, ZAMUDIO KR, GIOVANELLI JGR, HADDAD CFB, BALDISSERA JR FA AND ALEXANDRINO J. 2010. Phylogeography of endemic 
toads and post-Pliocene persistence of the Brazilian Atlantic Forest. Mol Phylogenet Evol 55(3): 1018-1031.

VALDUJO PH, SILVANO DL, COLLI G AND MARTINS M. 2012. Anuran species composition and distribution patterns in brazilian cerrado, a neotropical hotspot. S AM J Herpetol 7(2): 63-78.

VALOR NATURAL. 2005. Série Corredor Ecológico da Mantiqueira. Temas de Interesse para gestão ambiental. CD-ROM.

VALVERDE O. 1958. Estudo regional da Zona da Mata, de Minas Gerais. Rev Bras Geogr 1: 3-82.

VASCONCELOS EG AND GIARETTA AA. 2005. A new species of Hyla (Anura: Hylidae) from southeastern Brazil. Rev Esp Herpetol 17: 21-27.

VERDADE VK, DIXO M AND CURCIO FF. 2010. Os riscos de extinção de sapos, rãs e pererecas em decorrência das alterações ambientais. Estudos Avançados 24(68): 161172.
WERNER F. 1903. Neue Reptlilien und Batrachier aus dem naturhistorichen Museum in Brussel. Nebst bemerkungen uber einige anere Arten. Zool Anz 26: 246-253.

ZANELLA FCV. 2011. Evolução da Biota da Diagonal de Formações Abertas secas da América do Sul. In: Carvalho CJB and Almeida EAB (Eds), Biogeografia da América do Sul: padrões e processos, Editora Roca, São Paulo, Brasil, p. 198-220.

\section{SUPPLEMENTARY MATERIAL}

TABLE SI - Endemic species of Serra da Mantiqueira complex and South of Serra do Espinhaço and the status of conservation according to the International Union for Nature Conservation (IUCN 2016), the list of Brazilian endangered animals from the Instituto Chico Mendes de Conservação da Biodiversidade (ICMBio 2014), and the lists from Minas Gerais State (Drummond et al. 2008), Rio de Janeiro State (Bergallo et al. 2000), São Paulo State (Bressan et al. 2009), and Espírito Santo State (Passamani and Mendes 2007). 